\title{
Introduction: Connecting the universal to the particular
}

\author{
Stephen Roche
}

Published online: 19 February 2013

(C) Springer Science+Business Media Dordrecht 2013

The challenge of comparative education studies is to draw universal lessons from particular practices, and to envision localised practices based on universal principles. There is, of course, considerable risk inherent in this enterprise, for scholars and policymakers alike: what works well in one context may fail in another; and policy formulated with the noblest intentions may not fit reality on the ground. This twin caveat is of particular relevance to the four articles featured in this issue. The first two examine the effects of specific policy reforms in two very distinct educational contexts - Israel and China - while the latter focus on the difficulties of formulating and applying international data and policy recommendations.

Our opening article looks at how the concept of the professional learning community (PLC) has been applied in Israeli primary schools within the context of a national education reform programme. The author, Chen Schechter, first considers the core objective of a professional learning community: to dismantle the bureaucratic and mechanistic structures that heighten teachers' sense of isolation, replacing them with collaborative learning environments that support teachers and ensure a coordinated pedagogical approach. In a PLC, teachers reflect on and discuss their own practices, share knowledge and experiences through professional networks, actively collaborate to enhance the school learning environment, and engage in shared leadership with a facilitative and supportive school administration. The underlying premise is that if teachers are to foster the personal development of their students, the school must foster the personal development of teachers. Much recent scholarship has shown that collaborative learning leads to greater teacher commitment and student engagement, and significantly increases schools' ability to implement reform. In this study, the author sets out to identify factors that foster or inhibit the development of a PLC. He cites 45 interviews with teachers, their

S. Roche (两)

UNESCO Institute for Lifelong Learning, Hamburg, Germany

e-mail: s.roche@unesco.org 
principals and school superintendents (members of school oversight bodies). The findings indicate that the main factors inhibiting the healthy growth of a PLC are work overload, a lack of resources and top-down commands, while the principal's leadership style represents the main PLC-fostering factor.

If the move towards more inclusive and collaborative learning environments is one of the key educational trends of our day, the privatisation and marketisation of education is another. China, having embraced market economics in the early 1980s, re-opened its higher education sector to private enterprise in the early 1990s. However, far from emulating the astonishing success of its industrial sector, China's private universities have struggled to survive, with many failing outright (approximately 500 private universities shut down between 2000 and 2009). Xiaofan Li examines the roots of this failure, and recommends ways to turn failing private universities around. The author's analysis is based on principles of “organisational ecology", which applies insights from ecology to understand how organisations compete for resources, how external economic social and political conditions impact differently on organisations, and why some flourish while others decline. She considers several factors that contributed to poor performance, including insufficient resources, heavy government control, insufficient enrolments, lack of qualified teachers, limited programme breadth, and problems of scale. Notwithstanding their rough start, the author believes that private universities will survive in China, and, may indeed play a major role in achieving the government's target of a 40 per cent participation rate in higher education by 2020 .

Our third article deals with a further key trend in education: large-scale international assessment studies. Across all fields of education, comparable international testing data have become an important instrument in education policymaking. This article focuses on the International Adult Literacy Surveys (IALS) conducted by the Organisation for Economic Cooperation and Development (OECD). The author, Ralf St. Clair, provides a critical overview of the three studies conducted to date, providing practitioners and policymakers with guidance on how best to use these instruments. He points out the challenges involved in using these surveys to draw international comparisons, to document change over time, and to represent broad models of literacy. The tendency to use the survey findings for these purposes is considered by the author as a misuse of the data, which leaves the potential of the IALS surveys to provide insights into the effectiveness and equity of different educational systems largely untapped. In a clear and dispassionate analysis, he parses the pros and cons of drawing on the IALS surveys to inform policy decisions, and in doing so delivers a timely "handle with care" message to practitioners and policymakers.

Our final article likewise takes a global view, but of adult education policy rather than literacy. The author, Marcella Milana, examines the policy approaches to adult education and learning taken by the European Union (EU) and the United Nations Educational, Scientific and Cultural Organization (UNESCO). She shows that while UNESCO interprets adult education as a means for governments to overcome disadvantages experienced by their citizens, the EU regards it as a way to sustain regional economic growth and political expansion. Citing concerns about the development of a "common world educational culture" that "assumes the existence 
of a world polity", the author considers whether international policy convergence, and the accompanying encroachment on the autonomy of the nation-state, is legitimate. She cautions against an approach that views adult education either as a global concern or a national affair, pleading instead for a greater degree of connection between global conceptualisation and local implementation. She concludes by considering the effects of UNESCO's and the EU's discourses on adult education, in terms of liability (whom do governments consult when developing policy - their citizens or the international community?) and morality (who should decide what constitutes good policy and practice?). These questions go to the heart of the debate on the role of international governmental organisations in education.

As this is our final issue of 2012, I would like to acknowledge the mainstays of this and every peer-reviewed journal - our reviewers. For obvious reasons, we are precluded from mentioning them by name in each issue, but at minimal risk of compromising their anonymity, we would like to extend our gratitude and appreciation to the following individuals who reviewed articles for the International Review of Education in 2012:

Teresa Abada, University of Western Ontario Helen Abadzi, The World Bank, Washington DC

Deborah Adeyemi, University of Botswana, Gaborone

Cristian Aedo, The World Bank, Washington DC

Anies Al-Hroub, American University of Beirut

Steve Alsop, York University, Toronto

Joseph Ghartey Ampiah, University of Cape Coast

Beatrice Avalos, University of Chile, Santiago de Chile

Naz Awan, The British University in Dubai

Geneviève Barro, Université de Ouagadougou II

Jason Beech, Universidad de San Andrés, Buenos Aires

Zvi Bekerman, Hebrew University, Jerusalem

Paul Bélanger, Université du Québec à Montréal

Bettina Bochynek, UNESCO Institute for Lifelong Learning, Hamburg

Adams Bodomo, University of Hong Kong

Madina Bolly, UNESCO Institute for Lifelong Learning, Hamburg

Saouma B. BouJaoude, American University of Beirut

Birgit Brock-Utne, University of Oslo

Agnieszka Bron, Stockholm University

Guy Burton, London School of Economics

Genaro Castro-Vazquez, Nanyang Technological University, Singapore

Jasone Cenoz, University of the Basque Country, Donostia-San Sebastian

David W. Chapman, University of Minnesota, Minneapolis

David Coldwell, University of the Witwatersrand, Johannesburg

Corina Demetriou Lim, Symfiliosi, Nicosia, Cyprus

XiaoJiong Ding, Shanghai Academy of Educational Sciences

Mariam Jean Dreher, University of Maryland

Lorna Martha Dreyer, Stellenbosch University 
Jaap Dronkers, Maastricht University

Karen Evans, University of London

Márta Fülöp, Institute of Cognitive Neuroscience and Psychology, Budapest

Mekonnen Alemu Gebre Yohannes, Mekelle University

Charles Glenn, Boston University

César Guadalupe, Universidad del Pacifico, Lima

Ulrike Hanemann, UNESCO Institute for Lifelong Learning, Hamburg

Ruth Hayhoe, University of Toronto

Paul Hendriks, Radboud University Nijmegen

Kathleen Anne Heugh, University of South Australia, Magill

Halla Holmarsdottir, Oslo and Akershus University College

Ali Ibrahim, United Arab Emirates University, Al-Ain

Timothy D. Ireland, Federal University of Paraiba

Swarna Jayaweera, Centre for Women's Research, Colombo

Richard Kahn, Antioch University, Los Angeles

Thierry Karsenti, Université de Montréal

Brij Kothari, Indian Institute of Management, Gujarat

Marko Kwaramba, University of Cape Town

Rebecca Nthogo Lekoko, University of Botswana, Gaborone

Evelin Gerda Lindner, Human Dignity and Humiliation Studies, Oslo

Aïcha Maherzi, Université de Toulouse II

Suseela Malakolunthu, University of Malaya, Kuala Lumpur

Jyri Manninen, University of Eastern Finland, Joensuu

Hideki Maruyama, National Institute for Educational Policy Research, Tokyo

Vandra Masemann, Ontario Institute for Studies in Education, Toronto

Veronica McKay, University of South Africa, Pretoria

Michael McVey, Eastern Michigan University, Ypsilanti

Nagwa Megahed, American University in Cairo

Julien Mercier, Université du Québec à Montréal

Kurt Meredith, University of Northern Iowa, Cedar Falls

Stanley Mpofu, National University of Science and Technology, Bulawayo

Abdul Hameed Nayyar, Princeton University

Norbert Nikièma, Université de Ouagadougou

Julia Preece, University of KwaZulu-Natal

Gabriella Pusztai, University of Debrecen

Wapula Raditloaneng, University of Botswana, Gaborone

Savya Saachi, Jamia Millia Islamia, New Delhi

Justin Sandefur, Center for Global Development, Washington DC

Michael Schratz, University of Innsbruck

M. Najeeb Shafq, Indiana University, Bloomington

Daniel Sifuna, Kenyatta University, Nairobi

Darko Štrajn, Educational Research Institute, Ljubljana

Einami Swai, Open University of Tanzania, Dar-es-Salaam

Juliet Tembe, Islamic University in Uganda, Mbale

R. Murray Thomas, University of California, Santa Barbara

Malcolm Tight, Lancaster University 
Raúl Valdes-Cotera, UNESCO Institute for Lifelong Learning, Hamburg Javier M. Valle, Universidad Autónoma de Madrid

Eric van Lente, National University of Ireland, Galway

Erik van Schooten, University of Amsterdam

Ru-Jer Wang, National Taiwan Normal University, Taipei

Fuchaka Waswa, Kenyatta University, Nairobi

Joseph Zajda, Australian Catholic University, Fitzroy

Zeena Zakharia, Teachers College, Columbia University, New York 